\title{
Is it OK to laugh about it yet? Hitler Rants YouTube parodies in Hebrew
}

\author{
Liat Steir-Livny \\ Sapir Academic College \& The Open University, Israel \\ liatsteirlivny@gmail.com
}

\begin{abstract}
The Holocaust was and remains a central trauma in Israel's collective memory. For many years, the perception was that a humorous approach to the Holocaust might threaten the sanctity of its memory. Official agents of the Holocaust memory continue to believe in this approach, but since the 1990s, a new unofficial path of memory began taking shape in tandem with it. It is an alternative and subversive path that seeks to remember - but differently. In the last decade, YouTube has become a major cultural field including new humorous representations and images of the Holocaust. The article analyses a virtual phenomenon - "Hitler Rants" (or "Hitler Reacts") parodies in Hebrew. These are internet memes in which surfers take a scene from the German film Downfall (Oliver Hirschbiegel 2004), showing Hitler ranting at his staff as the end of WWII approaches, and they add parodic subtitles in which Hitler rants about completely different things - current affairs and pesky little details. The incompatibilities between the visuals, the German screaming, and the subtitles turn Hitler into a ludicrous individual. The article objects to the notion that views the parodies as "cheapening" the Holocaust, and rather claims that they underscore humour's role as a defence mechanism. Israelis, who live in a society in which the Holocaust memory is intensive and creates constant anxiety, seek to lessen reactions of tension and anxiety, even for a few minutes, and they do so through humour.
\end{abstract}

Keywords: Holocaust humour, Hitler, defence mechanisms, Israeli popular culture, social media, YouTube, incongruity theory; superiority theory; relief theory.

\section{Introduction: Holocaust humour and satire}

Holocaust humour is defined in research as humour that deals with issues and matters that are connected to the Holocaust: Hitler, Nazism, Holocaust, Holocaust memory, Holocaust survivors and their offspring. A humoristic representation of the Holocaust was seen as taboo in the West and particularly in Israel for several decades after the Holocaust. Between the 1940 s and the 1980s, very few films produced in the West dared to touch on the subject in a humorous manner. Debate in Israel on the subject was minimal and remained on the margins from statehood in 1948 until the 1990s. The prevalent position was that the combination of 
humour and the Holocaust disparages the Holocaust's status and makes fun of the magnitude of the trauma and suffering.

An extensive debate over the humorous representations of the Holocaust first began in the 1980s, when Art Spiegelman, in his graphic novel Maus: A Survivor's Tale (1986), rendered his Polish-born father's story of survival during World War II in a world of Nazi cats pitted against Jewish mice (Andreas 2001: 28-44). From then on, the combination of the Holocaust with humour was discussed more and more freely in Western research and popular culture (Lipman 1991; Kaplan 2003: 343-356; Wisse 2013: 143-181).

The film Life is Beautiful (Benigni 1997) spearheaded the way towards a deeper debate on the theme. In debates about the film, some argued that Benigni made a joke of the Holocaust, and many of its viewers and critics felt disquieted by a comedy ostensibly unfolding in an extermination camp, but which hardly addressed the atrocities of the Holocaust. Still others held that Benigni managed to instil a touching tragic-comic aspect into the film, which generated a powerful sense of the absurdity of racial theories (Kerner 2011: 79-100; Baron 2005: 135-170; Gonshak 2011: 229-250). In the last three decades, a growing number of comedians and humorists have dared to broach the subject in stand-up performances, TV sitcoms, films, YouTube videos, theatre, graphic novels, and other media (Steir-Livny 2015: 193-219).

A less visible process, regarding Holocaust humour and satire, echoing the one appearing in Western depictions, took place in Israel, but in a more cautious and hesitant way (SteirLivny 2014: 37-76; Zandberg 2015). The development of Holocaust humour is part of general changes in Holocaust awareness in Israel that both deepened and broadened its effect on the public in various cultural fields since the 1960s (Pinchevski \& Brand 2007: 387-407; Pinchevski \& Libes 2010: 265-291; Yablonka 2011: 175-242), and especially from the 1980s onwards, and have been thoroughly discussed in research (e.g. Ne'eman Arad 2003: 526; Ofer 2013: 70-85; Porat 2011: 357-378).

In 1997, Israelis fumed when on Holocaust Day, young people swapped coarse jokes on the internet. The reactions were divided into two groups: those who saw it as a healthy way of coping with the Holocaust in the present, and others who took issue with breaking the unyielding taboo on the subject (Loshitzky 2001: 152-178).

The success of Life is Beautiful, which was defined as "a comedy about the Holocaust" and its screening in Israel in 1999 again placed the subject on the public agenda, and reactions in Israel were divided into groups that were for or against it. Some viewers were offended, some even left in the middle of the screening. Others maintained that the representations of the Holocaust do not have to be realistic or possess documentary qualities. Those who supported the film contended that the angry critics of Life is Beautiful apparently were not aware of the unique role of humour and fantasy in attempts to survive (Ben-Dat 2015).

Since the 1990s, the subject began to be addressed in research. Adir Cohen in his book Living Life with Laughter (1994) analysed, among other subjects, Jewish jokes that were told by Jews in ghettos and concentration camps. In 2002, Ruth Bondi, a Holocaust survivor who documents the Jews of Czechoslovakia under Nazi occupation, described the contribution made by humour and satire for Jews in the Theresienstadt camp-ghetto. She described the songs, sketches, cabaret shows, and the satirical newspaper that were an integral part of life there (Bondi 2002: 61-80). The 2000s saw the publishing of two comprehensive books in Israel dealing with the importance of humour for Jews under the Nazi regime (Levin 2004; Ostrover 2009). Today, the debate over the subject in Israel is addressed in films, theatre, TV sitcoms and satire, stand-up appearances, internet videos, etc. Satirical skits that deal with the Holocaust have entered Israeli prime time, but such satire has yet to take hold in the JewishIsraeli collective memory. These depictions still ignite debate over the seemliness of 
humorous approaches toward the Holocaust (Zandberg 2006: 561-579; Steir-Livny 2014: 37-76).

\section{Hitler Rants parodies on YouTube}

Jokes about Hitler were already told underground during the Nazi regime (Levin 2004: 3769, Ostrover 2009: 49-97; Wisse 2013: 143-181). Charlie Chaplin had portrayed him in a ridiculous manner during WWII in The Great Dictator (1940); Mel Brooks made a caricature out of his image in The Producers (1968); contemporary sitcoms attach Hitler-like moustaches to characters they want to make fun of or to emphasise their violent behaviour, and he is both humanised and lampooned in films (Rosenfeld 2015: 234-292; Steir-Livny 2015: 193-219). In recent decades, the internet has become a wide cultural field for Hitler jokes with sites dedicated to cats with black markings under their nose that look like Hitler (also known as Kitler), which describe him as a cool hipster living in today's urban society (Hipster Hitler), and make fun of him in various clips on YouTube (Rosenfeld 2015: 292339). The most successful videos are the Downfall parodies, also known as Hitler Rants or Hitler Reacts memes.

Shifman (2013: 41) defines memes as “(a) a group of digital items sharing common characteristics of content, form, and/or stance, which (b) were created with awareness of each other, and (c) were circulated, imitated, and/or transformed via the Internet by many users". Hitler Rants memes are defined by her as part of a group called "egalitarian memes" memes that are based on a certain formula or genre. Surfers relate to a certain formula and modify the text.

Hitler Rants memes began appearing in August 2006. A Spanish web surfer took a scene from the film Downfall showing Hitler ranting at his staff as the end of the WWII approaches, and added parodic subtitles in Spanish, as if Hitler is criticising Microsoft's flight-simulator. An English speaking surfer uploaded the English subtitles version of this parody, making the joke accessible to the rest of the flight simulator fans on YouTube. From that time on, more and more surfers created their memes, and today there are hundreds of parodies in English, Spanish, Chinese, Japanese and many other languages (Ben-Ari 2010). These parodies discuss various subjects: politics, economy, sports, technology and gaming, culture and everyday trivialities, topical events, and trivial news or gossip. The parodies in English that have attracted the highest number of viewers present Hitler rants when he gets banned from Xbox live (9,105,511 views by 27 August 2016), when he is furious that Usain Bolt breaks the 100m World Record (3,782,991 views by 27 August 2016), and when he cannot stand the vuvuzela at the 2010 FIFA World Cup (3,583,585 views by 27 August 2016).

The success of these memes echo a combination of several theories of humour: mainly the superiority theory, the relief theory, and the incongruity theory (Rosenfeld 2015: 308312). At the basis of the superiority theory is the idea that the person who is laughing feels superior to the person who is the object of the laughter. If the object of laughter is an enemy, the intensity of the laughter and enjoyment increases (Sover 2009: 20-23). Along these lines, Hitler Rants memes show Hitler unable to face the trivial aspects of daily life. The scene, in all the memes, ends with Hitler sitting, looking defeated, his head slouched, thus increasing the feeling of superiority.

The incongruity theory refers to putting together conflicting ideas which show the incongruence between what is expected - the familiar and the known - and the real object found in the situation. Hitler becomes a comic character because of the contradiction between the myth (i.e. our knowledge about Hitler), the visual image (i.e. Hitler and his colleagues in 
a bunker during the Second World War) and the subtitles, which address completely different, mundane, and trivial matters, and drive him off balance (Gilbert 2013: 407-424).

The relief theory claims that laughter helps to relieve stress and anxiety for individuals and groups (Ostrower 2009: 28-38). In the case of the Hitler Rants memes, the devaluation and relief is also a form of revenge: the dictator who murdered millions of people is depicted as a little man who cannot deal with the challenges of everyday life.

The Downfall director, Oliver Hirschbiegel, said that he had seen many of the parodies and could see the merits of the idea (Ben-Ari 2010). Constantin Film, the production company of The Downfall was less pleased, and its managers began sending takedown notices to YouTube on April 2010. Martin Moszkowicz, head of film and TV at Constantin films in Munich, stated that he finds many of the parodies distasteful and trivial in light of the seriousness of the Holocaust and World War II. But the surfers did not give up. In order to bypass YouTube's visual-based copyright detection software, many contributors began applying the "mirror effect" on their parody uploads, flipping the original clip before adding subtitles (Dubs \& Brad 2013). "It is a task that can never be completed. They are popping up whenever we are taking one down", admitted Moszkowicz (Rohrer 2010). On October 2010, the Downfall Parodies Forum users reported that Constantin Film put an end to its YouTube blockade on The Downfall -derived parody videos, even placing advertisements on some of them (Dubs \& Brad 2013). The YouTube channel of these parodies is very successful and there are online technical explanations on how to create your own Hitler Rants parody. (Regarding the problem of the use of the copyrighted material in Hitler rants parodies, see Schwabach 2012.)

The huge success of the meme, and the fact that every surfer can easily prepare this parody has caused several incidents over the years. For instance, in December 2010, Jefferies Investment Bank executive Grant Williams was fired after sharing a Hitler Rants parody in a company newsletter email. In January 2012, Tom Harris, a Scottish Labour Party Member of Parliament uploaded a Hitler Rants parody on his personal YouTube channel, criticising the Scottish National Party leader Alex Salmond. The video was perceived as a comparison of Salmond to Hitler, and the public turmoil forced Harris to resign from his position (Dubs \& Brad 2013).

\section{Hitler Rants memes in Hebrew}

Hitler Rants parodies started appearing in Hebrew in 2009, and have become hugely popular. In Israel, these parodies are used to protest against political issues, Israeli wars, military service, religious coercion, etc. Many times these parodies engage in the irritating little details of daily life in Israel, such as skiing on Mount Hermon, the lack of weed to smoke, Israeli reality shows, Israeli rudeness. In addition, high school classes make Hitler Rants parodies for their end-of-school parties; IDF (Israeli Defence Forces) units create them to mark course graduations; high-tech employees send each other such parodies highlighting their specific companies' internal work issues and so on.

The parody that became the greatest success in Israel (according to view numbers) was Hitler mechapes hanaya betel-aviv ("Hitler is looking for a parking space in Tel Aviv"). It attracted more than 282,000 viewers (see www.youtube.com/watch?v=198kIhOQV24). In this parody, Hitler rants about the city's traffic problems: he is angry that his colleagues could not find a parking space anywhere in Tel Aviv and had to park in a bikers' parking area. He therefore got a parking ticket of $\$ 65$. He throws out of the room "those of you who live in Tel Aviv and have private parking places, or don't have a car", and, in a crazed monologue, 
begins complaining about his parking problems. He yells that the parking inspectors are vicious thieves:

They are all one big Mafia!

What are they thinking????

They don't have a shred of humanity!!

A shred of humanity!!

They are worse than the SS!!

And all the money goes to the corrupt municipality

They have been renovating the same tile near city hall for seven years!

When a Nazi officer explains that they have good intentions, they are adding a third traffic lane, Hitler cuts in brutally:

"Why the hell do I need a third lane??? They should build a public parking place!!"

The Nazi officer tries again: "But Sir, they built a public parking lot...", but it does not help. Hitler goes wild, screaming that in this new parking lot one can park only from 18:30 pm until 6 am:

"I arrived 10 minutes after 6:00 am

And I already found on the window of the car

A parking ticket $-\$ 65$ !

They towed my brother's car three times in one week

He pays more for parking tickets than he pays for gas!!

And all the money goes to the fucking mayor!

He has been the mayor for ten years!!

Who does he think he is???

He is worse than Stalin!!

And don't even start talking to me about public transportation!

Two hours!

Two hours I was waiting at the bus station!

I hate those buses!

And then two buses arrive at the station together!

What am I supposed to do??

Ride them both??

And then there is a traffic jam

Because some stupid woman driver

Tried to park reversing her car

And crashed into a traffic light

That anyway gives a green signal for only 3 seconds!

She should have her license revoked for good!

Maybe I'll sell my Volkswagen and that's it

I can sell it for five-six thousand dollars

Maybe someone is interested?

Maybe....We'll split the parking ticket

It's not worth having a car in Tel Aviv

I think I'll just take my stuff and go.

I'm sick and tired of this fucking city.

There is a parking place in Petah Tikva [a small town in Israel].

"Hitler is looking for a parking space in Tel Aviv" was so successful because it related to large audiences. Hitler rants parodies that appeared before it addressed narrow subjects that interested specific audiences. They were original, but not every Israeli could relate to them because of the very specific topics and insider jokes (e.g. the rivalry between football teams in Israel). The parking problems in Tel Aviv is a subject every Israeli knows, understands, 
and can relate to. The clever script is funny because it is so accurate. Working carefully on matches between the original dialogue of the scene and the Hebrew script (e.g. using the reference to Stalin at the exact moment Hitler says "Stalin" in the original scene, or translating words from German that most of the Israeli audience does not understand to curses in Hebrew that sound the same) increased the amusing feeling that Hitler was indeed ranting and raving about the parking problems in Tel Aviv. Since then, Hitler rants memes in Hebrew have spread like wildfire.

Hitler's most known visual images were portrayed in Leni Riefenstahl's film, Triumph of the Will (1934). In this film he was presented as a type of god, photographed from a low angle, in front of hundreds of admirers, as if he had immense, even mystic, powers (Avisar 1991: 38-47). In Hitler rants parodies, this "god" becomes a niggling, even pathetic individual who is stressed out by the irritating details of everyday life.

The reactions to Hitler rants parodies in Israel are mixed. Opponents claim that these parodies indicate that Jewish Israelis have no respect for our history and this is an educational problem. The creator of "Hitler is looking for a parking space in Tel Aviv" claims that he felt very bad when he heard that there were some Holocaust survivors who were offended by the parody. But then, he received many comments from people who told him that their grandmother or grandfather, Holocaust survivors, watched the parody, laughed and enjoyed it. He claims that the parody does not include offensive content and does not even mention Holocaust survivors; the only group that could be offended by it are Tel Aviv's city parking inspectors (Ben-Ari 2010). In any case, the opponents' reactions did not hurt their popularity. Hitler rants parodies in Hebrew are by now a proven success.

Culture researchers (Ben-Ari 2010) who were asked to explain this phenomenon in Israel have different opinions. Some claim that in today's world of mass media which floods us with text and visual images, one has to shout as strong as one can in order to be heard, otherwise the protest will get lost in the sea of other protests. Others (Dolev 2010: 36-38; Caril et al. 2011) claim that there is a built-in comic potential in the real historical image of the Führer, which explains why Hitler can be made into a laughing stock much more than other dictators. Some claim that this is an opportunity to gloat about Hitler, to show him in an inferior situation, in which he falls apart in the face of trivial problems. Others see the parodies as a sign of maturity: the ability to face the Holocaust in a different way than the canonic memory. Some see it as a sign of normalisation: the young generation wants to abandon the perception of the Holocaust as taboo, as untouchable, and this is one way to achieve it.

These explanations might be relevant for Hitler Rants parodies in the world, but I have checked the statistics for the number of Hitler Rants videos and views per speakers in the four languages in which the highest number of Hitler Rants videos were made: Hebrew, English, Spanish, and Polish, and the numbers indicate that in Israel, the number of viewers per Hebrew language speakers, and the number of parodies per Hebrew language speakers are proportionately much greater than other languages. This is demonstrated below. The numbers of native speakers were taken from Ethnologue: Languages of the World (2015). The data regarding the number of videos and views was accessed from YouTube in April 2015.

The first table shows the numbers of Hitler Rants videos and views per native speakers in the four languages in which the highest number of Hitler Rants videos was made: Hebrew, English, Spanish, and Polish. 
Table 1. The numbers of Hitler Rants videos and views per native speakers in Hebrew, English, Spanish and Polish

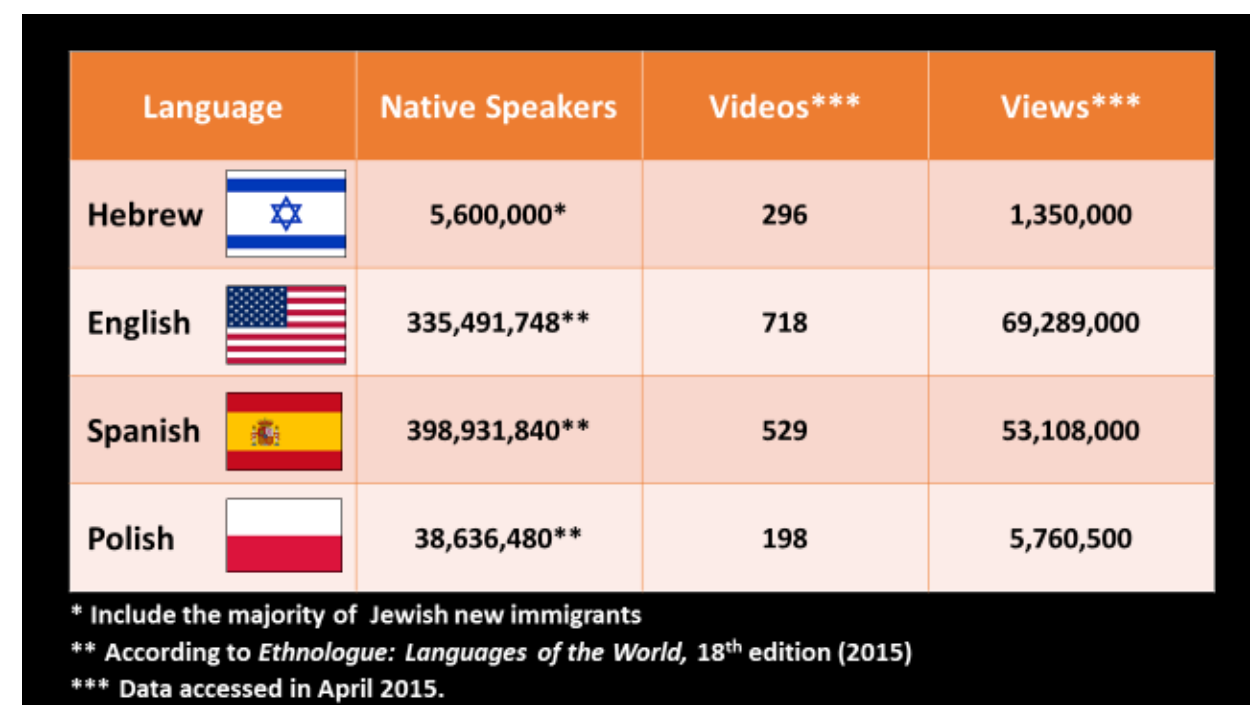

In the second table, the difference in views per native speakers can be seen: statistically, 1 of each 6.7 Polish native speakers (in Israel) viewed a Hitler Rants parody; For Spanish native speakers, 1 of 7.5; for English native speakers 1 of each 4.84; and 1 of each 4.14 Hebrew native speakers viewed a Hitler Rants parody.

Table 2. Views per native speakers

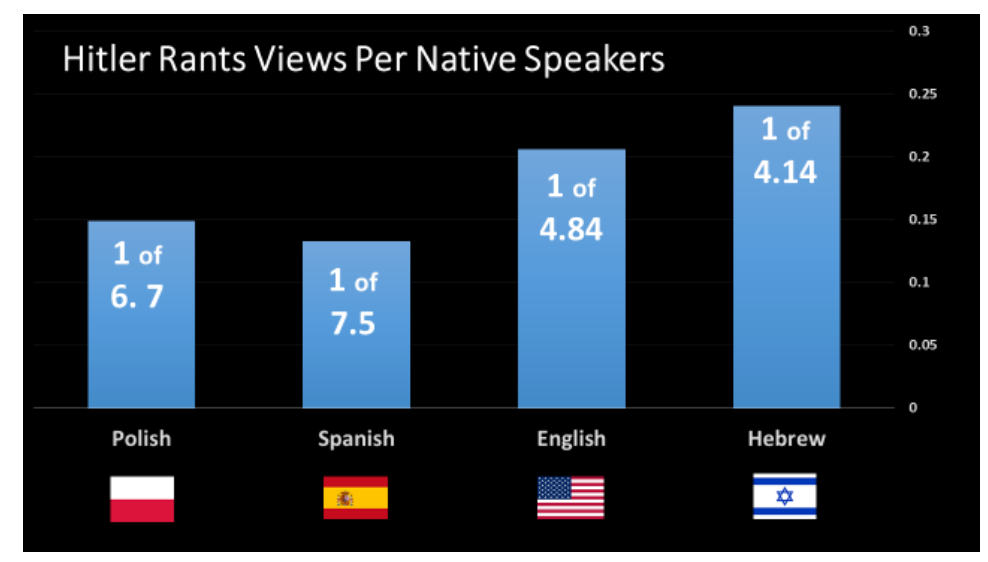

The third table deals with Hitler Rants videos per native speakers. The table shows a huge difference between Hebrew native speakers who created Hitler Rants videos and Polish, English and Spanish native speakers who created these videos. Statistically, the number of Hebrew native speakers who created Hitler Rants videos is 10 times higher than Polish native speakers, 24 times higher than English native speakers and 40 times higher than Spanish native speakers. 
Table 3. Hitler Rants videos per native speakers

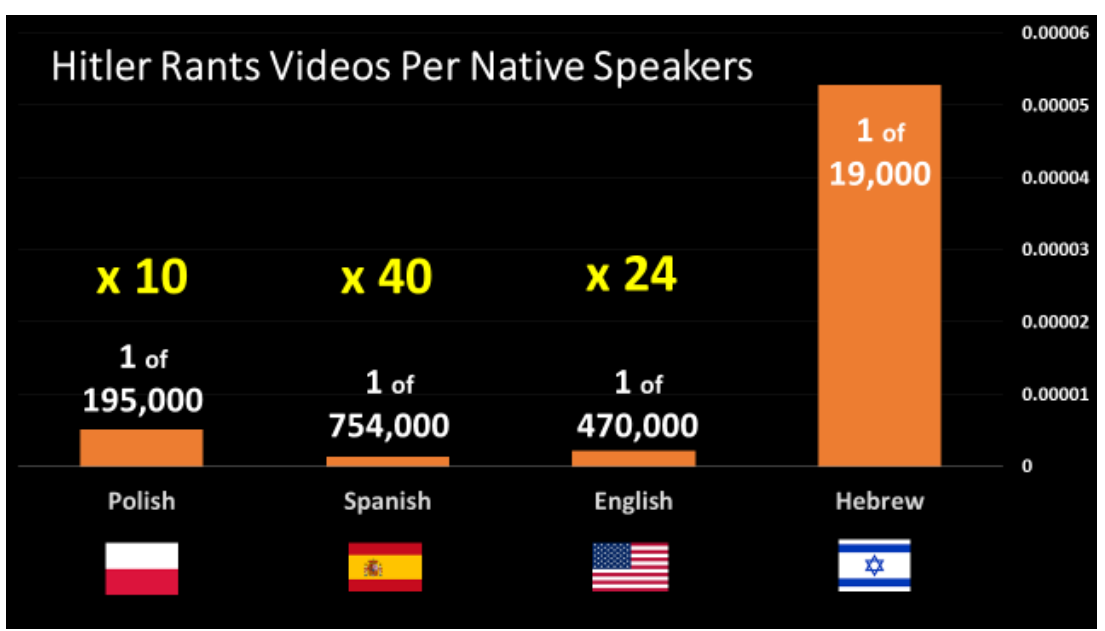

The tables show that the number of viewers per Hebrew language native speakers and the number of parodies per Hebrew language native speakers are proportionately much greater than other languages. This shows that even though Hitler Rants parodies are a worldwide phenomenon, they are much more successful and popular in Israel than in other places in the Western world. Therefore, I would like to add a different explanation to the phenomenon in Israel which will help to explain why in Israel these parodies are created and consumed in a capacity and intensity that exceed any other place in the world.

\section{Holocaust collective memory in Israel: Acting out, secondary stress, and defence mechanisms}

Freud (1988: 138-171) considered melancholy and mourning as two contradictory forms of coping with trauma: an individual in a melancholic state identifies with the lost object, obscuring the differences between the individual and the object, thereby damaging the ego. In mourning, in contrast, the mourner undergoes a healthy process of internalisation; he/she can deal with the past by creating distance from it. Mourning brings with it the possibility of starting a new life, and any disturbance of that process can become harmful. One of the central concepts in trauma is repetition compulsion - returning to the trauma while blurring the boundaries between past and present, and re-experiencing the original event. This repetition causes suffering and works against the desire of the sufferer; it is thus an uncontrolled compulsion to repeat.

Freud's disciples broadened the debate over trauma and its immediate and subsequent symptoms. Post-traumatic stress disorder (PTSD) is an extremely common mental disturbance among people who have experienced traumatic incidents. Its sufferers continue to experience the traumatic events for years afterwards, and a key characteristic of the syndrome is the sufferer's inability to sever him/herself from the events of the past (Herman 1994: 175195).

LaCapra (2000: 37-74) claims that the danger inherent in the disintegration of distinctions between different times and the merging of the traumatic past with the present is relevant not only for those who experienced the trauma in the flesh but also for groups that are linked with those traumas. Both groups and societies can become trapped in a situation that combines past and present, and reconstructs the trauma, or certain aspects of it, in different manners. Such post-traumatic symptoms can affect the group's behaviour in societal 
and political spheres. Following Freud, LaCapra distinguishes between two forms of collective memory of the Holocaust. The first is acting out: the past is not construed as a distant memory and internalised, but is reborn and experienced as if integral to present-day social and cultural life rather than as remote events that are long past. The second form is working-through: clear boundaries are maintained between past and present, and there is awareness of the differences between then and now. There is less identification with the assimilation of the traumatic period. While there is also a return to the past in workingthrough, it is accompanied by conscious control of the past, a critical distance from it, and a gaze at it from a perspective. Working-through is used as a sort of brake against posttraumatic repetition compulsion.

Goldberg (2000: 7-28) contends, following on the footsteps of LaCapra, that the way the Holocaust memory was shaped in Israel provides evidence for Israeli society as posttraumatic, and it exists in a state of acting out. He believes that the post-traumatic symptoms in Israel - chiefly reflected in the unending conflict with the Palestinians - attest to the collective trauma that has not been worked through appropriately. If Israelis are unable to work through it properly, he posits, their society is condemned to political repetition compulsion that has deadly results.

Another term that was introduced by Figley (1995: 1-20) and can be used to describe the Holocaust memory in Israel is secondary traumatic stress: indirect exposure to the trauma which affects those who were not involved in the traumatic events. Secondary traumatic stress can be found in friends and relatives of the traumatised persons well as in wider circles. Indirect exposure to a trauma through an intense cultural and media debate (television, radio, journalism, internet, etc.) can affect people who were not involved in the traumatic event (Jenkins \& Baird 2002: 423-432). PTSD symptoms, such as stress and anxiety, can appear in people who suffer from secondary traumatic stress, albeit less intensely.

Clinical research addresses Holocaust survivors as people who suffer from PTSD, and there are many debates over the question whether Holocaust survivors have transferred traumatic symptoms to their children (second-generation Holocaust survivors) and from them to their grandchildren (third-generation Holocaust survivors). But the trauma lives in much wider circles and affects all Jewish Israelis through intensive Holocaust awareness imbued by official memory agents. The Holocaust was and remains a central trauma in Israel's national consciousness. The memory of the trauma does not fade over the years; on the contrary, Holocaust representations and the public discourse regarding the Holocaust have only grown stronger in recent decades. Studies in Israel have shown that Holocaust memory has a very powerful presence, does not have just a one-generational impact, and is a cross-generational defining trait of the Jewish population in Israel (Steir-Livny 2014: 17-36).

Researchers claim that the Israeli media, educational and cultural fields, and the public discourse in Israel frame the Holocaust as a current, ongoing local trauma, rather than an event that ended decades ago in another place (Bar-Tal 2007: 112-137; Meyers et al. 2014: 153-165).

Surveys reveal that among the Jewish-Israeli population in general, since the 1940s, the Holocaust has been assimilated as a central event, and young Jewish-Israelis perceive the Holocaust as the historical event that has had the greatest impact on them and their future, even more than the founding of the State (Porat 2011: 357-378; Steir-Livny 2014: 17-36). Other research (Solomon 2007: 304-336) has shown that the knowledge that the second and third generation Holocaust survivors have about the Holocaust in Israel, and the way the Holocaust has shaped their identity is similar to those Israelis of the same age who are not biological offspring of Holocaust survivors. This phenomenon is very different from other places in the world, in which there is a huge gap in knowledge and perception of the 
Holocaust between biological offspring of Holocaust survivors and other Jewish people their age.

Moreover, in Israeli collective memory, the trauma of the Holocaust is not focused solely on events that occurred in the past. The sensitive relationships between Israel and the Arab nations, the decades-long Jewish-Arab conflict, the threat of annihilation, the continuing terrorist attacks and intifadas - all these have created an atmosphere of constant vigilance and ongoing anxiety. The length of the Jewish-Arab conflict and its violent nature also contribute to its wide-ranging and profound infiltration into Israel's sociocultural fabric (Ofer 2013). Since the State's earliest days, in addition to this fundamental condition of anxiety, the Holocaust's politicisation in Israel has intensified the place of the trauma in the everyday personal and collective psyche even more, by rendering the Holocaust a continuous event that affects the present and future. Since Israel's founding, the Holocaust has been connected with the Jewish-Arab conflict, creating cultural-media representations that draw parallels between Arabs and Nazis, between Israel's wars and the possibility of a "second Holocaust". Holocaust memory was and remains a crucial factor in the perceptions of the reality of the conflict. It intensifies anxiety levels among Jewish-Israelis and their sense of victimhood. The politicisation of the Holocaust has caused the trauma of the Holocaust to be integrated with Israeli present-day reality and replicated within it through the protracted Jewish-Arab conflict. This, in turn, has engendered a collective awareness of fear, insecurity, and constant anxiety stemming from the sense of existential danger (Bar-Tal 2007: 112-137).

Therefore, in Israel, the terms second-generation Holocaust survivors and thirdgeneration Holocaust survivors refer not only to the offspring of Holocaust survivors. They represent the Jewish-Israelis who were born after 1945 in Israel and grew up in an environment that focused on the Holocaust as one of the most important features in Jewish Israeli identity (Milner 2004: 19-35; Solomon 2007: 304-336).

This paper seeks to make the case that Hitler Rants parodies as well as many other humoristic and satirical texts regarding the Holocaust that appear in Israeli culture since the 1990s are an example of the way humour is used as a defence mechanism, by the JewishIsraelis in order to try to lessen reactions of tension and anxiety concerned with the extensive Holocaust awareness in Israel.

\section{Humour as a defence mechanism}

Freud (1990: 106-142) saw humour as a pivotal defence mechanism. He believed that when people use humour in situations that provoke their fear and anxiety, they gain a new perspective on the situation that helps them avoid experiencing negative emotions. With the help of humour, people can thus deal with difficult situations, and avoid or reduce their emotional suffering and grief. Later studies (Levin 2004: 13-36; Ostrover 2009: 63-104) addressed humour as a defence mechanism that helps individuals alleviate stress, cope with negative feelings and tough situations, mitigate suffering, dissipate feelings of anxiety - at least for a certain time - and grant them some sense of power and control in situations of helplessness. Humour can help those coping with unpleasant memories and aid trauma victims in reducing their tension and anxiety. It also helps people to maintain emotional distance from the trauma, creating a "comfort zone" for the traumatised person. As a defence mechanism, humour takes two forms: black humour and self-disparagement. Black humour deals with anxiety-producing subjects; attesting to this are its alternative terms: horror humour, sick humour, gallows humour, and grim humour. The therapeutic importance of black humour and self-disparagement for traumatised individuals has been frequently studied, and in a wide range of contexts (among victims of abuse, crime, disasters, etc.) particularly in 
the context of Jewish humour (Ziv 1998: 47-76). Black humour has been presented as an effective tool for an oppressed minority to withstand attacks by their oppressors; in the Jewish context, it constitutes the defence mechanism of an entire people (Sliwa 2011: 67-82; Wisse 2013: 59-103).

\section{Hitler rants memes in Hebrew: A defence mechanism against the acting out of the trauma}

Zandberg (2015) claims that since the 1990s, there has been an evolutionary development of the use of humorous skits on television and in other media in connection with the Holocaust. He suggests a four-phase typology of this process: the first, a "taboo" period until the 1990s in which Holocaust humour was not represented in Israeli culture. In the second phase, humour was used in order to explore and criticise Holocaust commemoration; in the third phase, humour about the Holocaust memory was used to comment on other social fields; and in the fourth phase, in the last few years, the Holocaust memory itself is used to create humour. He claims that this shift advocates a "normalisation" of the traumatic memory of the Holocaust.

Hitler Rants memes blur the boundaries between the third and fourth phases of this typology, because they are contemporary, most of them are used to comment on various social fields, and some of them are used as internal jokes, as noted, and as such they are seemingly used simply to create humour. But, in my opinion, even the more personal, intergroups Hitler memes are not simply raw material for laughter. The trauma is integrated so well in the Jewish-Israeli soul that every use of Holocaust humour has deep roots in the fear and anxiety created in a society that acts out the Holocaust and they function as defence mechanisms.

Figley (1995: 1-20) claims that in order to reduce symptoms that appear in PTSD and in secondary traumatic stress, one has to refrain from stimulations that are a reminder of the trauma. In Israel, refraining from Holocaust references is almost impossible, but there are other ways. In Hitler Rants parodies, the surfers silence (symbolically and actually as one) the original soundtrack that deals with Hitler, the Third Reich and the behaviour of absolute evil and, by doing so, silence the traumatic events. This is a provocation against the canonic memory of the Holocaust in Israel which replicates the Holocaust into Israeli everyday life as well as a defence mechanism against the anxiety it creates.

Memes' researchers claim that Internet memes are more than just simple jokes. They go beyond general silliness, and are to be taken seriously. They shape and reflect general social mindsets and can be used as a prism for understanding certain aspects of contemporary culture (Lankshear \& Knobel 2007: 1-24; Shifman 2013: 119-150). The fact that Hitler Rants memes are created and consumed in a capacity and intensity that exceed any other place in the world demonstrates the mental need of the younger generations to struggle against the "acting out" of the Holocaust and dismantle the symbols of fear in a society that is forced to relive the trauma.

These memes add yet another pillar to the struggle since they differ from other aspects of Holocaust humour and satire in Israel.

There is much research regarding the complex and diverse effects of digital social media, participatory media, and mass-popular platforms for user-created videos in which the circulation of content is increasingly driven by audiences who become the "producers" and not only the "consumers" (see among others Lankshear \& Knobel 2007: 1-24; Burgess \& Green, 2009: 58-74; Jenkins et al. 2013: 153-194). Research engages in the transfer from a top-down distribution model to a horizontal circulation model, in which the circulation of 
content is increasingly driven by audiences. Memes offer a new way of civic participation, where citizens are able to express political opinions and participate in important debates. This argument connects with other studies in the field of the new media, which discuss how online networks might inspire conventional political participation, and wonder how user-generated content may function as a mobiliser for citizens who are not usually able or willing to convey their political opinions in the traditional mass media (Rheingold 2008: 97-118; Shifman 2013: 119-150). Hitler Rants memes are thus part of a technological change that transferred the power to the individuals, the "small citizens" who are directly involved in the circulation of content. It is a part of a grassroots political and social movement, a bottom-up revolution against the forces that attempt to blur the past and present in order to achieve normalisation.

Humour which is based on repetition occurs when the recurring theme is comic to begin with. Each repetition of the same theme increases the comic gap. Laughter intensifies respectively, in accordance with the number of repetitions (Sover 2009: 126-127). The Hitler Rants memes feature the same bunker scene where Hitler reacts with outrage to a different issue each time. Thus it gives the creators of the parody and the viewers an intimate feeling of being part of a group with its own practices, its own humour, thus humour and memes have another function - social cohesion. In addition, it gives the creators the expression of individualism and creativity - they create their own original meme, with a script they have written.

Holocaust satire in Israel does not usually deal directly with the Holocaust but rather with its remembrance and commemoration (Shifman 2008: 143-150; Steir-Livny 2015: 193219; Zandberg 2015). Hitler is almost absent from this discussion. ${ }^{1}$ Hitler Rants parodies dare to enter the Holocaust realm and burst the bubble of fear, anxiety, and acting-out from within the historical event, while turning Hitler, until now almost untouchable in Israeli satire, into the protagonist. They emphasise the need to dismantle the fear and anxiety caused by the intense Holocaust remembrance in Israel, not only through a critique of the Israeli present, but also through dismantling the major symbol of evil. In this battle against the hegemonic memory of the Holocaust, Hitler, who is supposed to remain the symbol of evil in the young generations' consciousness turns into a friend, a buddy, the one who says what the "common Israeli" thinks.

Moreover, satirical programs such as The Chamber Quintet (Hahamishia Hakamerit; Matar Productions, Channel 2-Tela'ad, Channel 1, 1993-1997), It's a Wonderful Country (Eretz Nehederet; Keshet Productions, Channel 2-Keshet, 2003-2015), and the Nation's Back [Gav Hauma, Channel 10 2014-present, formerly, The State of the Nation (Mazav Hauma, Keshet Productions, Channel 2 2010-2014] also use Holocaust satire to protest against the hegemonic Holocaust remembrance in Israel (Zandberg 2006: 561-579; Shifman 2008: 143150; Steir-Livny 2014: 37-76). Hitler Rants memes are distinct from these skits because they are a unique case in which parody and satire combine. Parody imitates the style of someone or something else in an amusing way, creating a distorted imitation of something real in a funny way. Satire reflects the evils of society in a humorous way in order to change them. The memes do not just play with the figure of Hitler; they play with wider cultural and political problems (Gilbert 2013: 407-424). Hitler Rants memes in Hebrew are parodies about Hitler that dismantle the "acting out" of the Holocaust memory in Israeli society and simultaneously expose the absurd components of Israeli society in a satirical manner.

In addition, the Hitler Rants memes that address current issues add an important component of actuality to the struggle against hegemonic remembrance. They are distinct from the television skits because the web enables surfers to express their protest immediately, without the need to wait for a specific broadcast each week. A good example is the latest scandal regarding Prime Minister Binyamin Netanyahu and his statement on 20 October 2015 in his speech in the World Zionist Congress in Jerusalem, in which he stated that Hitler did 
not want to murder the Jews, but to expel them, and that it was the Arab Mufti, Haj Amin ElHusseini, who advised him to murder the Jews (see https://www.youtube.com/watch?v=kadhVdJ8hbk).

As noted, the politicisation of the Holocaust has appeared in Israeli society since the 1940s. It blended Holocaust associations with the Jewish-Arab conflict and has deepened feelings of fear and anxiety. Netanyahu's statement demonstrates the traumatic "acting out" (La Capra 2000: 87-90) and its subtext is clear: at a very tense time in Israel (OctoberNovember 2015) that some refer to as "the third Intifada", Netanyahu claims that every Arab - from the past to the present - is a Nazi. This comparison turns Jewish-Israelis into eternal victims, trapped in a repetitive Holocaust by the Nazis and the Palestinians combined.

The surfers responded immediately and a new Hitler Rants meme was released on the morning of October 21 and was shared in the social media, only several hours after Netanyahu's statement. In this meme, Hitler is presented as a great Jew lover who wants to help "the poor Jews", but is pushed to killer behaviour by the evil Mufti. This Hitler rants meme was part of a series of extensive online satiric responses to Netanyahu's speech (see e.g. Haaretz 2015). The Nation's Back addressed the absurdity of Netanyahu's declaration only in its program on 24 October with a long set of skits that referred to the "Arab Holocaust of the Jews". When The Nation's Back ridiculed this speech, it was, in today's terms, old news. This example emphasises how social networks enable the validation of features of instant healthy socio-cultural mourning, which is extremely important in a society in which the hegemonic collective memory tends towards the preservation of "acting out". The social media platforms enable young generations not only to nod in agreement while watching Holocaust skits on television, but to become an active part in the battle against "acting out". In a society drenched in anxiety and victimisation, this is a bottom-up revolution against the forces that attempt to blur the past and present in order to achieve normalisation, and move from "acting out" to "working-through".

Furthermore, there are many disputes in research on whether television attempts to preserve, even in this multicultural era, a sort of tribal campfire. Does it provide opportunities to undermine the hegemonic codes? Or should we address television as polysemic, typified by a combination of hegemonic and subversive positions? (Fiske 1987: 312-330). These questions become more complex where humorous skits are concerned due to humour's polysemous nature and the multiple meanings it inherently possesses (Meyer 2000: 310-333; Lynch 2002: 423-445; Shifman, 2008: 143-150; on the ambivalent perception of Holocaust satire in Israel, see Zandberg 2006; Shifman 2008). Satirists on Israeli television programs such as Gav haUmah and Eretz Nehedereth have to think twice before using Holocaust satire, and often have to apologise, even while on-air and sometimes after the show when dealing with letters of complaint (Steir-Livny 2015: 193-219). This set of apologies weakens the struggle against the hegemonic commemoration of the Holocaust and helps to reassure its boundaries. The social media platforms free Hitler Rants from the consideration of any aspect of hegemony powers and it turns them into a significant and central tool in the struggle against the "repetition compulsion" of the trauma.

In conclusion, objectors in Israel to Hitler Rants parodies consider them as "cheapening" and "degrading" the Holocaust (Ben-Ari 2010). As suggested above, these parodies represent the exact opposite: using Hitler as their mouthpiece in order to protest about everything from annoying little details to important political, economic, and social events - enables the surfers to fight the Holocaust's "acting out". It is a populist tool for political psycho-social repair. By so doing, the surfers do not ridicule or condemn the Holocaust, but rather they express how the Holocaust memory is an integral part of their identity. It is tattooed on their souls, and the anxiety it triggers pushes them to use black humour, not because they have 
detached themselves from the memory, but because they cannot detach themselves from the trauma.

\section{Notes}

1 There are two skits that refer to Hitler: 1) one that addresses young Hitler in the Academy of Arts in Vienna [The Jews are coming (Hayehudom baim) - the Arts Academy in Vienna, see https://www.youtube.com/watch?v=DVINXfIQU4I] and 2) another one that explains how and why Hitler stops the Holocaust [A place for concern (I) - calling off the Holocaust, see https://www.youtube.com/watch?v=zApo98-ScNs]. See Steir-Livny (2014).

\section{References}

Andreas, H. (2001). 'Of mice and mimesis: Reading Spiegelman with Adorno', in Zelizer, B. (ed.), Visual Culture and the Holocaust, New Brunswick, NJ: Rutgers University Press, pp. 28-44.

Avisar, I. (1991). 'Tiud veitzuv shel todaa historit besirtey taamula' [Documentation and visualisation of historic awareness in propaganda films], Zmnaim, 39-40, pp. 38-47.

Bakhtin, M. (1993). Rabelais and His World. Trans. Hélène Iswolsky. Bloomington: Indiana University Press.

Baron, L. (2005). Projecting the Holocaust into the Present: The Changing Focus of Contemporary Holocaust Cinema. Maryland: Rowman \& Littlefield.

Bar-Tal, D. (2007). Lihyot im hasichsuch [Living with the Conflict]. Haifa: Carmel.

Ben-Ari, G. (2010), 'Hitler matza hanaya' [Hitler found a parking space]. Yediot Aharonot, 26.2.2010. Retrieved March 30, 2014 from http://e.walla.co.il/?w=/267/1819879.

Ben-Dat, A. (2015). Bein humour letrauma bein etica leestetica [Between Humour and Trauma, Between Ethics and Aesthetics]. Tel Aviv: Resling.

Bondi, R. (2002). Shorashim Akurim [Displaced Roots]. Jerusalem: Yad vaShem.

Boskin, J. \& Dorinson, J. (1985). 'Ethnic humour: Subversion and survival'. American Quarterly. Special Issue: American Humour 37 (1), pp. 81-97.

Burgess, J. \& Green, J. (2009). YouTube: Online Video and Participatory Culture. Cambridge: Polity Press.

Caril, A., Shif, E. \& Shavit, A. (2001). 'Zohakim miTahat laSfam: Humour haShoah mehaHamishia Hakamerit vead Eretz Nehedered' [Holocaust humour: From the Hahamishia Hacamerit until Eretz. Nehederet]. Walla, 2.5.2011. Retrieved October 2, 2014 from http://e.walla.co.il/?w=/267/1819879.

Cohen, A. (1994). Haim bizhok [Living Life with Laughter]. Haifa: Amazia.

Dolev, I. (2010), 'Ma Pitom Hitler' [Why Hitler?]. Haaretz, Musaf Haaretz, 9.4.2010, pp. $36-38$.

Dubs, J. \& Brad. (2013). 'Downfall / Hitler Reacts', Know your Meme. Retrieved September 7, 2014 from http://knowyourmeme.com/memes/downfall-hitler-reacts.

Ethnologue: Languages of the World. (2015). $18^{\text {th }}$ edition.

Figley, C. R. (1995). 'Compassion fatigue as secondary traumatic stress disorder: An overview', in Figley, C. R. (ed.), Compassion Fatigue: Coping with Secondary Traumatic Stress Disorder in Those Who Treat the Traumatised, New York: BrunnerRoutledge, pp. 1-20.

Fiske, J. (1987). Television Culture. London: Routledge.

Freud, S. (1988). Hatipul ha-psichoanaliti [Psychoanalysis Treatment]. Tel Aviv: Am Oved. 
Gilbert, C. J. (2013). 'Playing with Hitler: Downfall and its ludic uptake'. Critical Studies in Media Communication 30 (5), pp. 407-424.

Goldberg, A. (2000), 'Introduction', in LaCapra, D. (ed.), Writing History, Writing Trauma, Baltimore, MD: Johns Hopkins University Press, pp. 7-28.

Gonshak, H. (2015). Hollywood and the Holocaust, Maryland: Rowman \& Littlefield Publishers.

Herman, J. L. (1994). Trauma ve hachlama [Trauma and Recovery]. Tel Aviv: Am Oved.

Jenkins S. R. \& Baird S. (2002). 'Secondary traumatic stress and vicarious trauma: A validation study'. Journal of Traumatic Stress, 15, pp. 423-432.

Kaplan, L. (2003). "It will get a terrific laugh": On the problematic pleasures and politics of Holocaust humour', in Jenkins, H., Shattuc, J. \& McPherson, T. (eds.), Hop on Pop: The Politics and Pleasures of Popular Culture, Durham: Duke University Press Books, pp. 343-356.

Kerner, A. (2011). Film and the Holocaust: New Perspectives on Dramas, Documentaries and Experimental Films, New York: Continuum Books.

LaCapra, D. (2000). Writing History, Writing Trauma. Baltimore, MD: Johns Hopkins University Press.

Lankshear, C. \& Knobel, M. (2007). 'Online memes, affinities, and cultural production', in Lankshear, C., Knobel, M., Bigum, C. \& Peters, M. (eds.), A New Literacies Sampler, New York: Peter Lang, 199-227.

Levin, I. (2004). Mibaad la-dmaot [Through the Tears: Jewish Humour under the Nazi Regime]. Jerusalem: Yad Vashem.

Life is Beautiful, dir. Roberto Benigni, 1997.

Lipman, S. (1991). Laughter in Hell: The Use of Humour During the Holocaust. NJ: Jason Aronson.

Lipman, S. (2008). 'Can a swastika be funny?'. The Jewish Week, 13.2.2008. Retrieved $\begin{array}{llll}\text { February 20, } 2014 & \text { from }\end{array}$ http://www.thejewishweek.com/features/can_swastika_be funny.

Loshitzky, Y. (2001). 'Hybrid victims: Second-generation Israelis screen the Holocaust', in Barbie, Z. (ed.), Visual Culture and the Holocaust, New York: Rutgers, pp. 152-178.

Lynch, O. H. (2002) 'Humorous communication: Finding a place for humour in communication research'. Communication Theory 12 (4), pp. 423-445.

Meyer, J. (2000). 'Humour as a double-edged sword: Four functions of humour in communication'. Communication Theory 10 (3), pp. 310-333.

Meyers, O., Neiger, M., \& Zandberg, E. (2014). Communicating Awe: Media Memory and Holocaust Commemoration. New York: Palgrave Macmillan.

Milner, I. (2004). Kirey avar [A Torn Past]. Tel Aviv: Chaim Weizmann Institute for the Study of Zionism and Israel, Tel Aviv University/Am Oved.

Morreall, J. (2011). 'Humour in the Holocaust: Its critical, cohesive, and coping functions'. Holocaust TRC, November 22. Retrieved September 20, 2014 from http://www.holocaust-trc.org/humour-in-the-holocaust.

Ne'eman Arad, G. (2003). 'Israel and the Shoah: A tale of multifarious taboos'. New German Critique 90, pp. 5-26.

Ofer, D. (2013). 'We Israelis remember, but how? The memory of the Holocaust and the Israeli experience'. Israel Studies 18 (2), pp. 70-85.

Ostrover, H. (2009). Lelo humour hainu mitabdim [If Not for Humour, We Would Have Committed Suicide]. Jerusalem: Yad Vashem.

Pinchevski, A. \& Brand, R. (2007). 'Holocaust perversions: The Stalags pulp fiction and the Eichmann Trial'. Critical Studies in Media Communication 24 (5), pp. 387-407. 
Pinchevski, A. \& Liebes, T. (2010). 'Severed voices: Radio and the mediation of trauma in the Eichmann Trial'. Public Culture 22 (2), pp. 265-291.

Porat, D. (2011). Café ha'boker ba'rayach ashan: mifgashim shel ha'yishuv va'ha'hevra ha'yisraelit im ha'shoah va'nitzoleha [The Smoke-Scented Coffee: The Encounter of the Yishuv and Israeli Society with the Holocaust and its Survivors]. Tel-Aviv/Jerusalem: Yad vaShem \& Am Oved.

Rheingold, H. (2008), 'Using participatory media and public voice to encourage public participation', in Bennet, L. (ed.), Civic Life Online: Learning How Digital Media Can Engage Youth, Cambridge: MIT press, pp. 97-118.

Rohrer, F. (2010). 'The rise, rise and rise of the Downfall Hitler parody'. BBC News Magazine, 13.4.2010. Retrieved May 2, 2013 from http://news.bbc.co.uk/2/hi/8617454.stm.

Rosenfeld, G. D. (2015). Hi Hitler: How the Nazi Past Is Being Normalised in Contemporary Culture. Cambridge: Cambridge University Press.

Schwabach, A. (2012). 'Reclaiming copyright from the outside in: What the Downfall Hitler meme means for transformative works, fair use, and Parody'. Buffalo Intellectual Property Law Journal. Retrieved January 5, 2017 from http://papers.ssrn.com/sol3/papers.cfm?abstract id=2040538.

Shifman, L. (2008). Haars, Hafreha ve-haima hapolaniya [Televised Humour and Social Cleavages in Israel, 1968-2000]. Jerusalem: Hebrew University Magnes Press.

Shifman, L. (2013). Memes in Digital Culture. Cambridge: MIT Press.

Sliwa, J. (2011). 'Jewish humour as a source of research on Polish-Jewish relations', in Greenspoon, L. J. (ed.), Jews and Humour, West Lafayette, IN: Purdue University Press, pp. 67-82.

Solomon, Z. (2007). 'Hashpaot beindoriot shel hshoah beri hamechkar beisrael' [Transgenerational influences of the Holocaust in Israeli research], in Solomon, Z. \& Chaitin, J. (eds.), Yaldut bezel haShoah [Childhood in the Shadow of the Holocaust], Tel Aviv: Hakibbutz Hameuhad, pp. 304-336.

Sover, A. (2009). Bedarco shel haadam hazohek [The Pathway to Human Laughter]. Jerusalem: Carmel.

Spiegelman, A. (1986). Maus: A Survivor's Tale. Pantheon Books.

Steir-Livny, L. (2009). Shtei Panim baMaraah [Two faces in the mirror]. Jerusalem: Eshkolot-Magness.

Steir-Livny, L. (2014). Har hazikaron yizkor bimkomi [Let the Memorial Hill Remember]. Tel Aviv: Resling.

Steir-Livny, L. (2015). 'Holocaust humour, satire, and parody on Israeli television'. Jewish Film and New Media 3 (2), pp. 193-219.

The Great Dictator, dir. Charlie Chaplin, 1940.

The Producers, dir. Mel Brooks, 1968.

Triumph of the Will, dir. Leni Riefenstahl, 1934.

Wisse, R. (2013). No Joke: Making Jewish humour. Princeton: Princeton University Press.

Yablonka, H. (2001). Medinat Israel neged Adolf Eichmann [The State of Israel against Adolf Eichmann]. Tel Aviv: Yediot Aharonot.

Zandberg, E. (2006). 'Critical laughter: Humour, popular culture and Israeli Holocaust commemoration'. Media, Culture \& Society 28 (4), pp. 561-579.

Zandberg, E. (2015). "Ketchup is the Auschwitz of tomatoes": Humour and the collective memory of traumatic events'. Communication, Culture \& Critique 8 (1), pp. 108-123.

Ziv, A. (1998). 'Psycho-social aspects of Jewish humour in Israel and in the diaspora', in Ziv, A. (ed.), Jewish Humour, New Brunswick: Transaction Publishers, pp. 47-76. 
'The web does delicacies of Netanyahu, Hitler and the Mufti'. Haaretz, 21 October 2015. Retrieved January 7, 2017 from http://www.haaretz.co.il/captain/viral/1.2757423. 